\title{
Impact of meteorological parameters on extracted landfill gas composition and flow
}

\author{
Fathi Aghdam, Ehsan; Scheutz, Charlotte; Kjeldsen, Peter
}

Published in:

Waste Management

Link to article, DOI:

10.1016/j.wasman.2018.01.045

Publication date:

2019

Document Version

Peer reviewed version

Link back to DTU Orbit

Citation (APA):

Fathi Aghdam, E., Scheutz, C., \& Kjeldsen, P. (2019). Impact of meteorological parameters on extracted landfill gas composition and flow. Waste Management, 87, 905-914. https://doi.org/10.1016/j.wasman.2018.01.045

\section{General rights}

Copyright and moral rights for the publications made accessible in the public portal are retained by the authors and/or other copyright owners and it is a condition of accessing publications that users recognise and abide by the legal requirements associated with these rights.

- Users may download and print one copy of any publication from the public portal for the purpose of private study or research.

- You may not further distribute the material or use it for any profit-making activity or commercial gain

- You may freely distribute the URL identifying the publication in the public portal

If you believe that this document breaches copyright please contact us providing details, and we will remove access to the work immediately and investigate your claim 
Manuscript accepted for publication in Special Issue on Landfill Gas Emission Monitoring in Waste Management journal:

https://doi.org/10.1016/j.wasman.2018.01.045

\title{
Impact of meteorological parameters on extracted landfill gas composition and flow
}

\author{
Ehsan Fathi Aghdam*, Charlotte Scheutz, Peter Kjeldsen
}

Department of Environmental Engineering, Technical University of Denmark, 2800 Kgs. Lyngby, Denmark

* Corresponding author: ehag@env.dtu.dk, phone number: +45 45251498 


\begin{abstract}
The objective of this study was to investigate the impact of four pre-selected meteorological parameters (barometric pressure, wind speed, ambient temperature and solar radiation) on recovered landfill gas (LFG) flow, methane $\left(\mathrm{CH}_{4}\right)$ content of the $\mathrm{LFG}$ and the recovered $\mathrm{CH}_{4}$ flow by performing statistical correlation tests and a visual check on correlations in scatterplots. Meteorological parameters were recorded at an on-site weather station, while LFG data were recorded when entering the gas engine. $\mathrm{LFG} \mathrm{CH}_{4}$ concentration, $\mathrm{LFG}$ flow and $\mathrm{CH}_{4}$ flow correlated highly with both barometric pressure and changes in barometric pressure, and the correlations were statistically significant. A higher correlation was observed when studying changes in barometric pressure in comparison to the absolute value of barometric pressure. LFG recovery data were correlated highly and significantly with wind speed during winter, but not during summer. Ambient temperature and solar radiation were not major meteorological parameters affecting LFG recovery, as low correlation coefficients were observed between these two parameters and the LFG recovery data.
\end{abstract}

\title{
Keywords
}

Barometric pressure; ambient temperature; wind speed; solar radiation; correlation 


\section{Introduction}

Landfill gas (LFG), consisting of methane $\left(\mathrm{CH}_{4}: 55-60 \% \mathrm{v} / \mathrm{v}\right)$ and carbon dioxide $\left(\mathrm{CO}_{2}: 40-45 \%\right.$ $\mathrm{v} / \mathrm{v}$ ), is generated by disposing of biodegradable waste in landfills. Landfills contribute to global warming as $\mathrm{CH}_{4}$ is a greenhouse gas with a global warming potential 28 times that of $\mathrm{CO}_{2}$ (IPCC, 2013). Landfills are one of the major anthropogenic sources of $\mathrm{CH}_{4}$ emissions to the atmosphere. $\mathrm{CH}_{4}$ emission from landfills and wastewater sector combined was estimated to account for $18 \%$ of the global anthropogenic $\mathrm{CH}_{4}$ emissions in 2004 (Bogner et al., 2008).

$\mathrm{CH}_{4}$ generated in landfills can be collected by installing vertical or horizontal gas wells and then utilised for the production of electricity and heat. Landfill $\mathrm{CH}_{4}$ generation, collection and emission are influenced by many factors, including meteorological parameters (Scheutz et al., 2009). It is important to understand the impact of these parameters on LFG collection and composition, in order to regulate the gas collection system accordingly, aiming at greater $\mathrm{CH}_{4}$ extraction.

A higher extraction of $\mathrm{CH}_{4}$ from landfills results in a lower contribution to global warming by reducing $\mathrm{CH}_{4}$ emissions. Moreover, it can result in higher revenue for landfill owners by producing more electricity and heat. For instance, an increase in landfill $\mathrm{CH}_{4}$ extraction of $10 \mathrm{Nm}^{3} / \mathrm{h}$ corresponds to an $\mathrm{CO}_{2}$ emission reduction to the atmosphere of approximately 1640 ton $\mathrm{CO}_{2}$ eq/year and an energy production of 3145 GJ/year when assuming a lower heating value for $\mathrm{CH}_{4}$ of 35.9 MJ/Nm${ }^{3}$ (Waldheim and Nilsson, 2001). With an average annual Danish household electricity consumption of $3448 \mathrm{kWh}$, corresponding to 12.4 GJ (Kitzing et al., 2016), a $10 \mathrm{Nm}^{3} / \mathrm{h}$ higher extraction of landfill $\mathrm{CH}_{4}$ can cover the electricity consumption of 253 households in Denmark.

A number of previous studies have investigated the impact of meteorological parameters on LFG composition, emissions and extraction (Table 1). Barometric pressure is the most studied parameter. The majority of the studies (Fredenslund et al., 2010; Gebert and Groengroeft, 2006; Nastev et al., 
2001; Poulsen et al., 2003; Xu et al., 2014; Young, 1992, 1990) have found that it is the changes in barometric pressure, rather than its absolute value, that affects emissions from a landfill. However, Czepiel et al. (2003) found that measured $\mathrm{CH}_{4}$ emissions at Nashua municipal landfill, USA, correlated inversely with the absolute value of barometric pressure. Christophersen et al. (2001) found that LFG emissions, measured by flux chambers at a Danish landfill, correlated inversely with both barometric pressure and changes in barometric pressure, but a better correlation was observed with changes in barometric pressure.

The impacts of soil and air temperature on LFG emissions and LFG composition have also been studied previously (Christophersen et al., 2001; Czepiel et al., 2003; Uyanik et al., 2012). Christophersen et al. (2001), for instance, found that air and soil temperature had a significant influence on LFG emissions, while Czepiel et al. (2003) found no significant correlation between air temperature and $\mathrm{CH}_{4}$ emissions. Uyanik et al. (2012) found that soil temperature is an important factor affecting the composition of recovered LFG.

A few studies have looked at the impact of wind speed (Poulsen, 2005; Xin et al., 2016), wind direction (Xu et al., 2014) and solar radiation (Xin et al., 2016) on LFG emissions. Poulsen (2005) simulated LFG emissions at a Danish landfill and concluded that wind speed affects LFG emissions especially in winter. Xin et al. (2016) measured diel $\mathrm{CH}_{4}$ emissions, using flux chambers at a Chinese landfill, and observed that $\mathrm{CH}_{4}$ fluxes were affected highly by solar radiation during daytime and by wind speed at night. $\mathrm{Xu}$ et al. (2014) measured $\mathrm{CH}_{4}$ emissions from a U.S. landfill, using the eddy covariance method, and found no influence of wind direction on the measured $\mathrm{CH}_{4}$ emissions. 
1 Table 1. Overview of previous studies on the impact of meteorological parameters on LFG emission and extraction. Table includes the

\begin{tabular}{|c|c|c|c|}
\hline Reference & Studied parameter(s) & Methodology & Main findings \\
\hline $\begin{array}{l}\text { Christophersen et al. } \\
\text { (2001) }\end{array}$ & $\begin{array}{l}\text { Barometric pressure, } \\
\text { soil moisture, air and } \\
\text { soil temperature }\end{array}$ & $\begin{array}{l}\text { Using measured } \mathrm{CH}_{4} \text { and } \mathrm{CO}_{2} \text { emissions from } \\
\text { a landfill with flux chambers, in order to study } \\
\text { correlations. }\end{array}$ & $\begin{array}{l}\text { Barometric pressure, barometric pressure gradient, soil moisture, air and } \\
\text { soil temperature had a significant influence on LFG emissions. }\end{array}$ \\
\hline Czepiel et al. (2003) & $\begin{array}{l}\text { Barometric pressure } \\
\text { and air temperature }\end{array}$ & $\begin{array}{l}\text { Using measured } \mathrm{CH}_{4} \text { emissions from a landfill } \\
\text { by the tracer dispersion method. }\end{array}$ & $\begin{array}{l}\text { Measured landfill } \mathrm{CH}_{4} \text { emissions significantly correlated with the } \\
\text { absolute value of barometric pressure; no significant correlation was } \\
\text { observed between air temperature and } \mathrm{CH}_{4} \text { emissions. }\end{array}$ \\
\hline Fredenslund et al. (2010) & Barometric pressure & $\begin{array}{l}\text { Using measured } \mathrm{CH}_{4} \text { emissions from a } \\
\text { leachate well at a landfill by using the tracer } \\
\text { dispersion method. }\end{array}$ & $\begin{array}{l}\text { Changes in barometric pressure had a significant impact on measured } \\
\mathrm{CH}_{4} \text { emissions. }\end{array}$ \\
\hline $\begin{array}{l}\text { Gebert and Groengroeft } \\
\text { (2006) }\end{array}$ & Barometric pressure & $\begin{array}{l}\text { Using measured passively vented LFG flow } \\
\text { rates and composition entering a biofilter. }\end{array}$ & $\begin{array}{l}\text { The measured LFG flow rate and composition were affected by the } \\
\text { gradient of atmospheric pressure and not by its absolute value. }\end{array}$ \\
\hline Nastev et al. (2001) & Barometric pressure & $\begin{array}{l}\text { Simulation of LFG generation, emissions and } \\
\text { migration by fitting site-specific data into a } \\
\text { model. }\end{array}$ & Changes in barometric pressure affect LFG emissions. \\
\hline $\begin{array}{l}\text { Nwachukwu } \\
\text { Anonye (2013) }\end{array}$ & Barometric pressure & $\begin{array}{l}\text { Using recorded } \mathrm{CH}_{4} \text { and } \mathrm{CO}_{2} \text { concentrations at } \\
\text { a landfill with an in-borehole ground-gas } \\
\text { monitor. }\end{array}$ & $\begin{array}{l}\text { Barometric pressure was the major control on LFG composition during } \\
\text { periods of falling pressure, but not during periods of rising pressure. }\end{array}$ \\
\hline Poulsen (2005) & Wind speed & $\begin{array}{l}\text { Simulation of LFG emissions by using } \\
\text { measured } \mathrm{CO}_{2} \text { concentrations near a landfill } \\
\text { edge. }\end{array}$ & Wind speed affects LFG emissions, especially in winter. \\
\hline Poulsen et al. (2003) & $\begin{array}{l}\text { Barometric pressure } \\
\text { and soil moisture }\end{array}$ & $\begin{array}{l}\text { Using a numerical model fitted to site-specific } \\
\text { data, to quantify the impacts of different } \\
\text { meteorological parameters. }\end{array}$ & Soil moisture and changes in barometric pressure affect LFG emissions. \\
\hline Uyanik et al. (2012) & $\begin{array}{l}\text { Soil temperature and } \\
\text { air temperature }\end{array}$ & $\begin{array}{l}\text { Using the recorded composition of the } \\
\text { recovered LFG. }\end{array}$ & $\begin{array}{l}\text { Soil temperature was the most important meteorological parameter } \\
\text { affecting recovered LFG composition. }\end{array}$ \\
\hline Xin et al.(2016) & $\begin{array}{l}\text { Solar radiation, } \\
\text { ambient temperature, } \\
\text { soil temperature and } \\
\text { wind speed }\end{array}$ & $\begin{array}{l}\text { Using measured } \mathrm{CH}_{4} \text { and } \mathrm{CO}_{2} \text { emissions from } \\
\text { a landfill by the flux chamber, in order to } \\
\text { study the correlation. }\end{array}$ & $\begin{array}{l}\mathrm{CH}_{4} \text { fluxes correlated highly with solar radiation and temperatures } \\
\text { during daytime and with wind speed at night. }\end{array}$ \\
\hline Xu et al. (2014) & $\begin{array}{l}\text { Barometric pressure } \\
\text { and wind direction }\end{array}$ & $\begin{array}{l}\text { Using measured } \mathrm{CH}_{4} \text { and } \mathrm{CO}_{2} \text { emissions from } \\
\text { a landfill, using the eddy covariance method. }\end{array}$ & $\begin{array}{l}\text { Changes in barometric pressure affected landfill } \mathrm{CH}_{4} \text { emissions; no } \\
\text { influence of wind direction on measured } \mathrm{CH}_{4} \text { emissions. }\end{array}$ \\
\hline Young $(1992,1990)$ & Barometric pressure & Modelling of LFG emissions. & LFG emission rate depends on the rate of change in barometric pressure. \\
\hline
\end{tabular}


Gas transport in landfills with an active gas collection system depends on the suction pressure applied in the gas collection system. Only two of the studies listed in Table 1 were performed on landfills with an active gas collection system (Czepiel et al., 2003; Uyanik et al., 2012). Uyanik et al. (2012) however, focused only on the impact of air and soil temperature on the recovered LFG composition, while Czepiel et al. (2003) studied the impact of barometric pressure on $\mathrm{CH}_{4}$ emissions, but not on $\mathrm{CH}_{4}$ extraction.

The objective of this study was to investigate the impact of meteorological parameters (barometric pressure, ambient temperature, wind speed and solar radiation) on recovered LFG flow, $\mathrm{CH}_{4}$ concentrations of recovered LFG and recovered $\mathrm{CH}_{4}$ flow. Moreover, the impact of changes in barometric pressure was studied and compared with the impact of the absolute value of barometric pressure. The objective was met by performing statistical analyses on collected meteorological data and gas recovery data during four periods in 2015 and 2016.

\section{Material and methods}

\subsection{Landfill sites description}

Odense Nord and Stige Ø landfills are located in Odense, Denmark. Stige Ø landfill was established in 1964 and received several types of waste, including municipal solid waste, until 1994. After 1994, the landfill received only soil until 2005, when it was closed. The landfill contains around 7 million tons of waste and soil, and it covers an area of 56 hectares. Stige $\varnothing$ landfill is today a recreational area. The majority of Stige $\varnothing$ surface is covered with 1 meter of soil. In some areas the cover is slightly thicker due to the construction work of Odense municipality to convert the landfill to a recreational area with different facilities for outdoor activities. 
The Odense Nord landfill has received different types of waste, including mixed waste, shredder waste and mineral waste, since 1994 and is still in operation. The shredder waste is disposed in the eastern part of the site, covers an area of 6.5 hectares (34\% of the area of the Odense Nord landfill with gas collection system) and is not finally covered. The cell with mixed waste covers an area of 12.6 hectares and consists of three sections. One section is finally covered with approximately $10 \mathrm{~m}$ of soil, one section with 1-3 $\mathrm{m}$ of soil, and one section is still in operation and therefore not covered. The bottom liner in Odense Nord landfill consists of a HDPE membrane placed on top of a clay layer. A composting facility is located at the northern part of the site. A map of Odense Nord (with its different sections) and Stige Ø landfills is presented in Fig. 1.

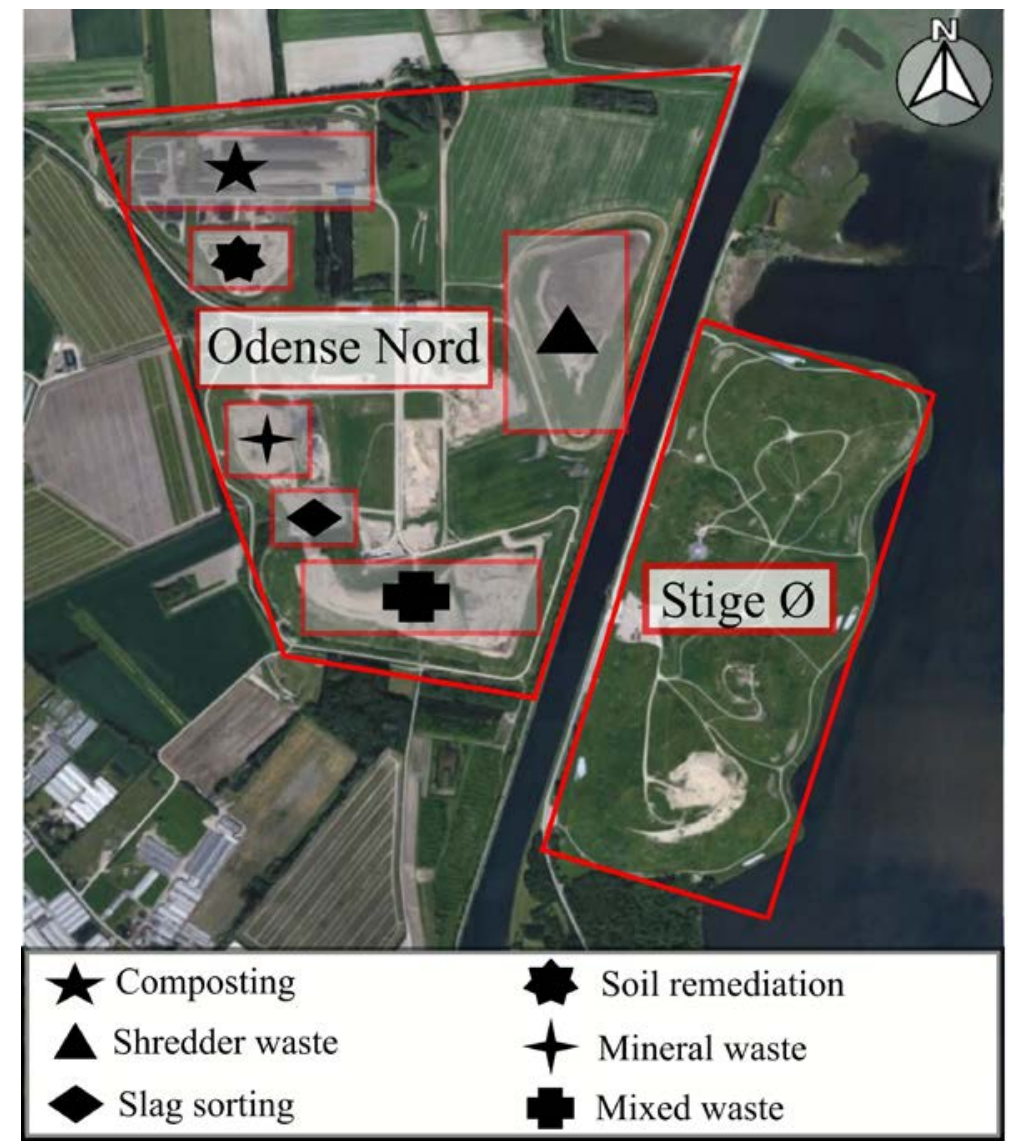

Fig. 1. Map of Odense Nord (left) and Stige Ø (right) landfills (Imagery @2016 Google, Aerodata International Surveys, Digital Globe, Map data (2016 Google). 
At Stige Ø landfill, a gas recovery facility is installed consisting of 160 vertical gas wells, which are connected to four measuring, pump and regulation modules (MPR module). These four MPR modules are connected to two compressors. In Odense Nord, LFG is only collected from the cells with mixed waste and shredder waste. There are 19 vertical and 10 horizontal gas wells in the cell containing mixed waste, and these are connected to an MPR module and a compressor, while there are 27 vertical gas wells in the cell containing shredder waste, which are connected to an MPR module and a compressor. At these six MPR modules, LFG is pumped by compressors (Tamrotor F22 BG, Gardner Denver, USA) and the LFG flow is measured by flow meters (V-Cone, Masstrol, KEP, USA) installed on each gas well. These six MPR modules are connected to a local power plant, where a gas engine (Jenbacher JMS 312 GS LL, GE Power, USA) and a boiler produce electricity and heat.

Approximately $60 \%$ of the total collected LFG flow originates from Stige $\varnothing$ landfill and $40 \%$ from

Odense Nord landfill. The LFG flow rate and its $\mathrm{CH}_{4}, \mathrm{CO}_{2}$ and $\mathrm{O}_{2}$ content entering the local power plant are measured at the power plant by a flow meter (Prosonic Flow B 200, Endress+Hauser, Switzerland) and two analysers (Binos 100 and Oxynos 100, Fisher-Rosemount, Germany) and the data is stored. The analysers are calibrated weekly by landfill operators using $50 \% \mathrm{CH}_{4}, 50 \% \mathrm{CO}_{2}$, $100 \% \mathrm{~N}_{2}$ and atmospheric air, while a more thorough calibration with more calibration gases is done once per year at an external company (FLSmidth Airloq, Denmark).

\subsection{Data collection}

The LFG flow rates $\left(\mathrm{m}^{3} \mathrm{LFG} / \mathrm{h}\right)$ at normal temperature and pressure (NTP; $\left.\mathrm{T}=293.15 \mathrm{~K}, \mathrm{P}=1 \mathrm{~atm}\right)$, and the $\mathrm{CH}_{4}$ content of the LFG (v/v \%) entering the gas engine, were recorded every two minutes. $\mathrm{CH}_{4}$ flow rates $\left(\mathrm{Nm}^{3} / \mathrm{h}\right)$ were calculated by multiplying the recovered LFG flow rates by their 
corresponding $\mathrm{CH}_{4} \mathrm{v} / \mathrm{v} \%$ entering the gas engine. These data were then converted to hourly averages, to be used for statistical analysis (section 2.3).

Four periods were chosen for this study: 11.08.2015-06.09.2015, 15.08.2016-25.08.2016, 05.09.201611.09.2016 and 05.12.2016-08.12.2016. The three periods in 2016 were combined and is presented as one dataset for 2016. The four periods were chosen because no manual adjustments were performed on the gas extraction system during these periods. On some occasions, one or more of the modules was stopped for a short time, due to technical problems. These periods were identified in collaboration with the landfill operators, and the corresponding data were removed from the dataset.

Barometric pressure (mbar), ambient temperature $\left({ }^{\circ} \mathrm{C}\right)$, wind speed $(\mathrm{m} / \mathrm{s})$ and solar radiation $\left(\mathrm{W} / \mathrm{m}^{2}\right)$ were the recorded meteorological parameters. The collected meteorological data were hourly averages, recorded at an on-site weather station (MAWS301L/QMBAT Central, Vaisala, Finland). Moreover, in order to study the impact of changes in barometric pressure on LFG composition and flow, whole periods were divided into sub-periods based on increasing and decreasing pressure. Then changes in barometric pressure and corresponding changes in LFG $\mathrm{CH}_{4}$ concentration, LFG flow and $\mathrm{CH}_{4}$ flow were calculated for each sub-period. Furthermore, the gradient of these changes over time was calculated by dividing the changes by the number of hours in each sub-period. Finally, statistical analyses were performed on the calculated numbers.

\subsection{Statistical analysis}

In order to investigate if there is a correlation between meteorological parameters (barometric pressure, ambient temperature, wind speed and solar radiation) and LFG data collected from the two landfills, correlation coefficients and p-values were calculated. The Spearman method was used in this study 
(Reimann et al., 2008) which gives a correlation coefficient between -1 and +1 showing how strongly the two variables are correlated. Correlation coefficients of -1 and +1 show a perfect linear relationship between the two variables, while 0 shows that there is no correlation. Negative correlation coefficients show an inverse relationship, i.e. when one variable increases the other decreases, while positive values show a direct relationship between the two variables (Reimann et al., 2008).

Moreover, p-values were calculated in this study, to show whether the correlation coefficients were significantly different from zero: $\mathrm{p}<0.001$ shows very high significance, $0.001 \leq \mathrm{p}<0.01$ shows high significance, $0.01 \leq \mathrm{p}<0.05$ shows significance, $0.05 \leq \mathrm{p}<0.10$ shows weak significance and $\mathrm{p} \geq$ 0.10 shows no significance (Reimann et al., 2008). The statistical analyses were carried out with $\mathrm{R}$ statistical software (R Core Team, 2017), using the StatDA package (Filzmoser, 2015).

\section{Results and discussion}

\subsection{Impact of meteorological parameters on $\mathrm{LFG} \mathrm{CH}_{4}$ concentration, $\mathrm{LFG}$ flow and $\mathrm{CH}_{4}$ flow}

Table 2 shows the calculated correlation coefficients ( $r$ ) and p-values between meteorological parameters (barometric pressure, ambient temperature, wind speed and solar radiation) and LFG data (LFG $\mathrm{CH}_{4}$ concentration, $\mathrm{LFG}$ flow and $\mathrm{CH}_{4}$ flow entering the gas engine). Moreover, correlation coefficients between LFG CH 4 concentration and LFG flow in 2015 and 2016 were calculated (not

shown in Table 2), which showed a strong and inverse correlation between the two variables (absolute value of $\mathrm{r}$ between 0.49-0.98). The correlation between $\mathrm{LFG} \mathrm{CH}_{4}$ concentration and LFG flow was statistically significant $(p<0.001)$ and observed also visually in scatterplots (Fig A1 in the Supplementary Material (SM)). 
Table 2. Correlation coefficients and p-values between meteorological parameters and LFG data during the periods studied in 2015 and 2016.

\begin{tabular}{|c|c|c|c|c|c|}
\hline Year & Parameters & $n^{\mathrm{a}}$ & $\begin{array}{l}\text { LFG } \mathrm{CH}_{4} \text { concentration } \\
\text { (\%) }\end{array}$ & $\begin{array}{l}\text { LFG flow } \\
\left(\mathrm{Nm}^{3} / \mathrm{h}\right)\end{array}$ & $\begin{array}{l}\mathrm{CH}_{4} \text { flow } \\
\left(\mathrm{Nm}^{3} / \mathrm{h}\right)\end{array}$ \\
\hline \multirow{4}{*}{2015} & Barometric pressure (mbar) & \multirow{4}{*}{600} & $-0.73(\mathrm{p}<0.001)$ & $0.51(\mathrm{p}<0.001)$ & $-0.37(p<0.001)$ \\
\hline & Ambient temperature $\left({ }^{\circ} \mathrm{C}\right)$ & & $-0.12(p \geq 0.10)$ & $0.27(p<0.001)$ & $0.19(p<0.001)$ \\
\hline & Wind speed $(\mathrm{m} / \mathrm{s})$ & & $0.15(p<0.001)$ & $-0.22(p<0.001)$ & $-0.02(p \geq 0.10)$ \\
\hline & Solar radiation $\left(\mathrm{W} / \mathrm{m}^{2}\right)$ & & $-0.07(0.05 \leq p<0.10)$ & $0.03(p \geq 0.10)$ & $-0.04(p \geq 0.10)$ \\
\hline \multirow{4}{*}{2016} & Barometric pressure (mbar) & \multirow{4}{*}{444} & $-0.56(p<0.001)$ & $0.64(p<0.001)$ & $0.01(p \geq 0.10)$ \\
\hline & Ambient temperature $\left({ }^{\circ} \mathrm{C}\right)$ & & $0.47(p<0.001)$ & $-0.49(p<0.001)$ & $0.27(p<0.001)$ \\
\hline & Wind speed (m/s) & & $-0.25(p<0.001)$ & $0.27(p<0.001)$ & $-0.06(p \geq 0.10)$ \\
\hline & Solar radiation $\left(\mathrm{W} / \mathrm{m}^{2}\right)$ & & $0.20(p<0.001)$ & $-0.21(p<0.001)$ & $0.08(0.05 \leq p<0.10)$ \\
\hline
\end{tabular}

a $n$ : number of observations.

\subsubsection{Barometric pressure}

Between the studied meteorological parameters, barometric pressure showed the highest correlation coefficients with LFG $\mathrm{CH}_{4}$ concentration, LFG flow and $\mathrm{CH}_{4}$ flow. Barometric pressure showed quite strong negative correlation with LFG $\mathrm{CH}_{4}$ concentration ( $\mathrm{r}=-0.73$ and -0.56 in 2015 and 2016, respectively) and a positive correlation with LFG flow ( $r=0.51$ and 0.64 in 2015 and 2016, respectively), and both correlations were found to be significant $(p<0.001)$. This means that higher barometric pressure resulted in lower $\mathrm{LFG} \mathrm{CH}_{4}$ concentrations and a higher LFG flow entering the gas engine. The reason for this could be that at higher barometric pressures, more air had flowed into the landfill, which resulted in a higher recovered LFG flow rate, while the recovered LFG was more diluted and thus had a lower $\mathrm{CH}_{4}$ concentration. Barometric pressure showed a lower correlation coefficient with $\mathrm{CH}_{4}$ flow entering the gas engine in $2015(\mathrm{r}=-0.37)$. However, the correlation was statistically significant $(p<0.001)$. 
Fig. 2 illustrates barometric pressure against LFG CH 4 concentration (2a), LFG flow (2b) and $\mathrm{CH}_{4}$ flow (2c) during the period 11.08.2015-06.09.2015. From the figure it is evident that higher barometric pressure corresponded with lower $\mathrm{LFG} \mathrm{CH}_{4}$ concentrations, higher LFG flow and lower $\mathrm{CH}_{4}$ flow. As an example, a barometric pressure reading of 1027 mbar (on 21.08.2015 11:00) corresponded to an LFG $\mathrm{CH}_{4}$ concentration of $30.9 \%$, an LFG flow of $482 \mathrm{Nm}^{3} / \mathrm{h}$ and a $\mathrm{CH}_{4}$ flow of $149 \mathrm{Nm}^{3} / \mathrm{h}$, while a

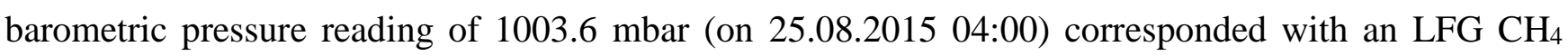
concentration of $34.3 \%$, an LFG flow of $457 \mathrm{Nm}^{3} / \mathrm{h}$ and a $\mathrm{CH}_{4}$ flow of $157 \mathrm{Nm}^{3} / \mathrm{h}$.

To our knowledge, the impact of barometric pressure on LFG collection data has not been studied previously. However, an inverse correlation was observed between barometric pressure and $\mathrm{CH}_{4}$ emission rate, measured using the tracer dispersion method, by Czepiel et al. (2003) at a U.S. landfill. In the study by Czepiel et al. (2003), the highest $\mathrm{CH}_{4}$ emission rate of $1590 \mathrm{~m}^{3} / \mathrm{h}$ was measured at a barometric pressure of 1007 mbar, while the lowest $\mathrm{CH}_{4}$ emission rate of $438 \mathrm{~m}^{3} / \mathrm{h}$ was measured at a pressure of 1023 mbar. Pressure difference is the driving force for advective gas transport (Scheutz et al., 2009). At higher barometric pressures, the pressure difference between inside the landfill and the atmospheric air decreases (Christophersen et al., 2001), resulting in a lower advective gas emission. 

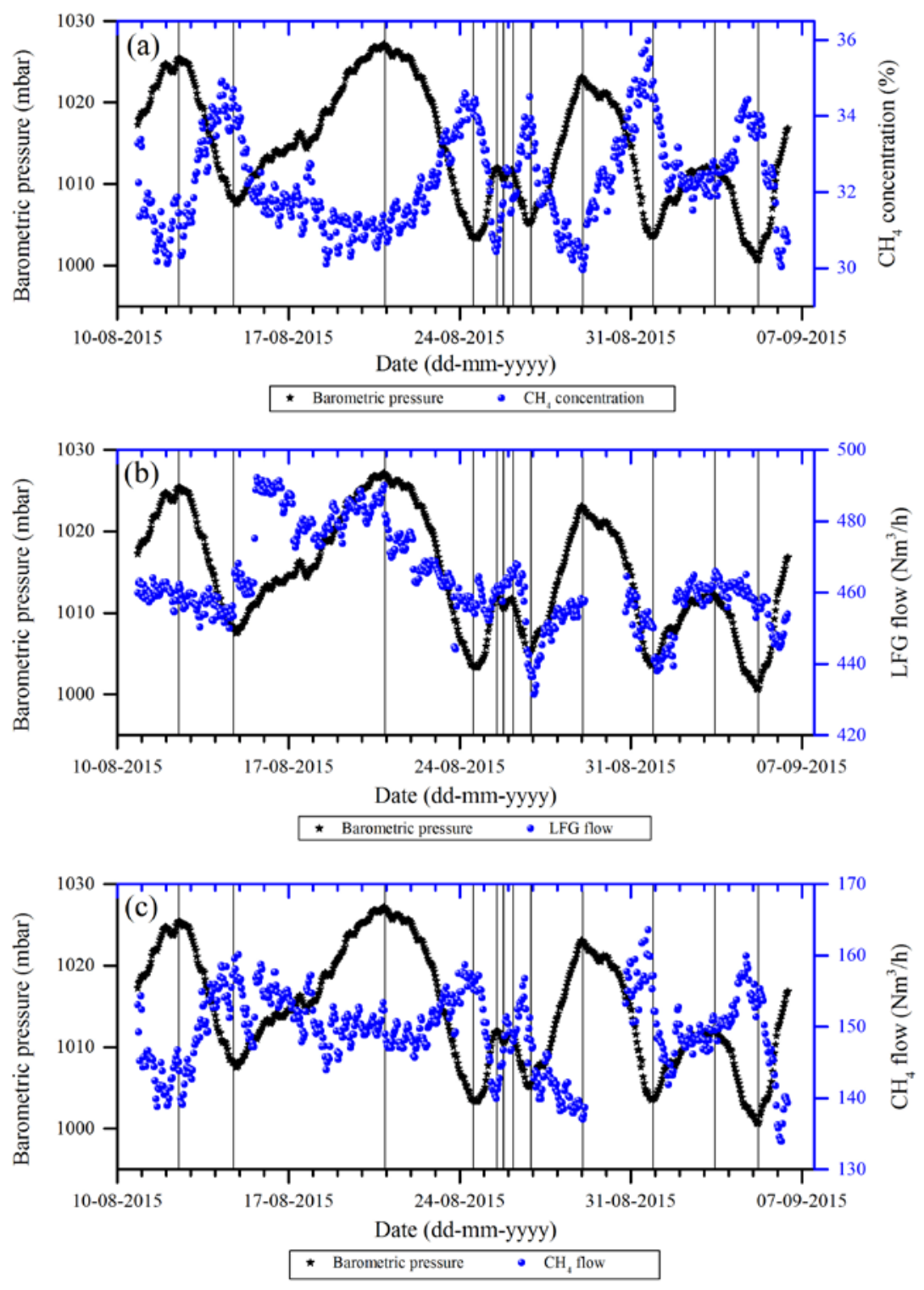

Fig. 2. Barometric pressure (mbar) against LFG $\mathrm{CH}_{4}$ concentration (\%), LFG flow $\left(\mathrm{Nm}^{3} / \mathrm{h}\right)$ and $\mathrm{CH}_{4}$ flow $\left(\mathrm{Nm}^{3} / \mathrm{h}\right)$ during the period 11.08.2015-06.09.2015. LFG flows and $\mathrm{CH}_{4}$ flows from Saturday 29.08.2015 at 16:00 to Monday 31.08.2015 at 07:00 are missing, as one of the MPR modules was stopped, due to technical problems. The black vertical lines show the division into sub-periods based on increasing and decreasing pressure tendencies (section 3.2).

No strong or significant correlation was observed between barometric pressure and $\mathrm{CH}_{4}$ flow in 2016 ( $\mathrm{r}$ $=0.01, p \geq 0.10$ ). The average $\mathrm{CH}_{4}$ collection rate in the studied period of 2015 was $149 \mathrm{Nm}^{3} / \mathrm{h}$, while 
it was $170 \mathrm{Nm}^{3} / \mathrm{h}$ in 2016. The higher $\mathrm{CH}_{4}$ collection rate in 2016 was due to the commencement of gas extraction from the second section of the shredder waste cell in May 2016. According to the landfill operators, the gas engine had reached its maximum capacity in 2016, and thus it could not burn more $\mathrm{CH}_{4}$. This resulted in automatically regulating the gas engine to reduce suction pressure, when $\mathrm{CH}_{4}$ concentrations increased, in order to maintain a constant $\mathrm{CH}_{4}$ flow to the engine. Fig. 3 shows barometric pressure against $\mathrm{LFG} \mathrm{CH}_{4}$ concentration (3a), LFG flow (3b) and $\mathrm{CH}_{4}$ flow (3c) entering the gas engine during the period 05.12.2016-08.12.2016. Barometric pressure against $\mathrm{LFG} \mathrm{CH}_{4}$ concentration, LFG flow and $\mathrm{CH}_{4}$ flow during the rest of the studied periods in 2016 are shown in Figs. $\mathrm{A} 2$ and $\mathrm{A} 3$ of the SM.

It is evident from Figs. 3c, A2c and A3c that even though barometric pressure is changing, $\mathrm{CH}_{4}$ flow remains fairly constant, while Fig. 2c shows a clear response of $\mathrm{CH}_{4}$ flow to barometric pressure in 2015. The regulatory action of the gas engine, resulting in a fairly constant $\mathrm{CH}_{4}$ flow, is most likely the reason for the very low correlation coefficient $(\mathrm{r}=0.01)$ between barometric pressure and $\mathrm{CH}_{4}$ flow in 2016. The higher correlation coefficient between barometric pressure and LFG flow in 2016, in comparison to 2015, could also be due to a synergic impact of the regulatory measure of the gas engine and barometric pressure on LFG flow in 2016. 

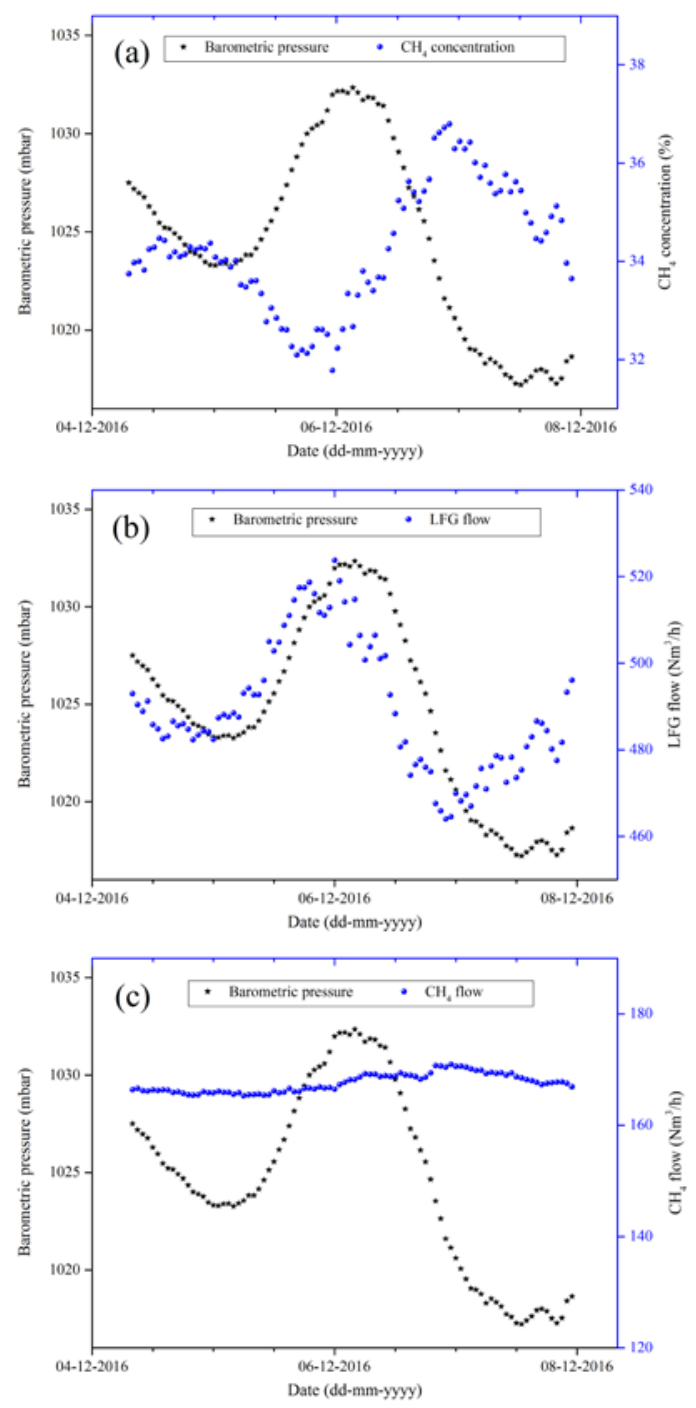

Fig. 3. Barometric pressure (mbar) against LFG $\mathrm{CH}_{4}$ concentration (\%), LFG flow $\left(\mathrm{Nm}^{3} / \mathrm{h}\right)$ and $\mathrm{CH}_{4}$ flow $\left(\mathrm{Nm}^{3} / \mathrm{h}\right)$ during 05.12.2016-08.12.2016.

\subsubsection{Ambient temperature}

Weak correlation coefficients were observed between ambient temperature and LFG data (Table 2). Moreover, weak correlation coefficients (absolute value of $r$ between 0.04-0.41) were observed between ambient temperature and LFG data during the three periods in 2016, when the periods were studied individually. Fig. 4 shows ambient temperature against LFG CH 4 concentration (4a), LFG flow 
(4b) and $\mathrm{CH}_{4}$ flow (4c) during 11.08.2015-06.09.2015. Graphs for ambient temperature against LFG data, during the studied periods in 2016, can be found in the SM (Figs. A4-A6). No visual correlation was observed between ambient temperature and LFG data, which shows that ambient temperature does not affect LFG collection rates or composition in these landfills. Temperature affects the volume of gases, at constant pressure, according to the ideal gas law. However, in this study the gas volumes were converted to NTP to avoid this impact.
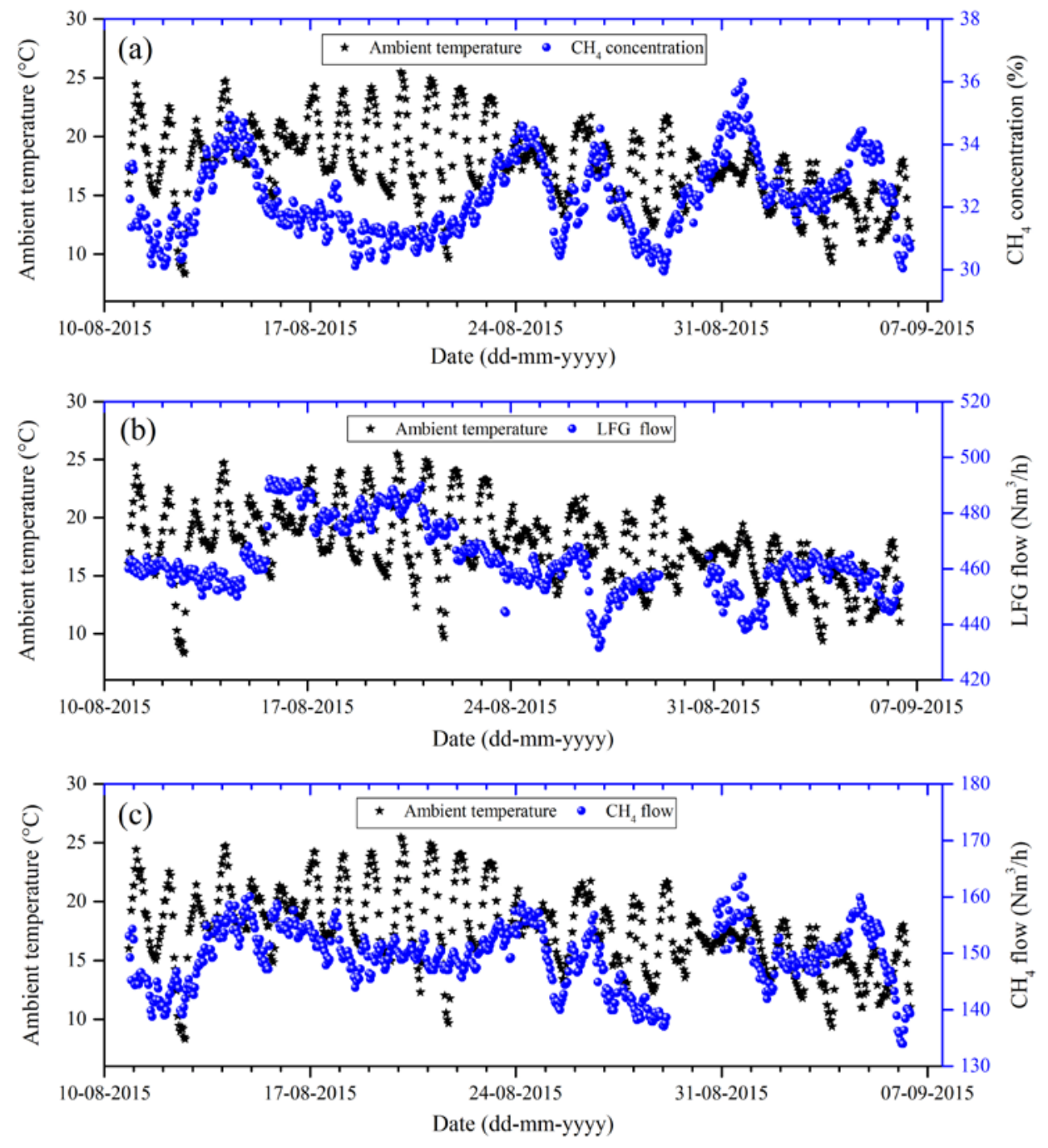

Fig. 4. Ambient temperature $\left({ }^{\circ} \mathrm{C}\right)$ against LFG $\mathrm{CH}_{4}$ concentration (\%), LFG flow $\left(\mathrm{Nm}^{3} / \mathrm{h}\right)$ and $\mathrm{CH}_{4}$ flow $\left(\mathrm{Nm}^{3} / \mathrm{h}\right)$ during 11.08.2015-06.09.2015. 
Biological processes such as anaerobic digestion and microbial $\mathrm{CH}_{4}$ oxidation are influenced by temperature, in that higher temperatures lead to higher microbial activities and result in higher $\mathrm{CH}_{4}$ generation rates or $\mathrm{CH}_{4}$ oxidation rates (Chen et al., 2008; Scheutz et al., 2009). Earlier studies have shown $\mathrm{CH}_{4}$ emissions to correlate inversely with soil and ambient temperatures (Börjesson and Svensson, 1997; Christophersen et al., 2001), which most likely is caused by changes in microbial $\mathrm{CH}_{4}$ oxidation in the landfill cover being higher at higher temperatures, thus dampening $\mathrm{CH}_{4}$ emissions (Chanton and Liptay, 2000; Scheutz et al., 2009). Obviously, the processes in the landfill cover will be affected by ambient temperature.

However, at most landfills, the temperature inside the waste body will be elevated in comparison to the ambient temperature. Temperatures of up to $64{ }^{\circ} \mathrm{C}$ inside landfills have been reported in previous studies (Hanson et al., 2010; Olsen and Willumsen, 2013). Anaerobic digestion of organic waste in landfills produces heat (Hanson et al., 2010), and as the landfills in this study have waste heights or depths of $20-30 \mathrm{~m}$, it is highly likely that the produced heat by anaerobic digestion of waste is maintained inside the body of the landfills. Thus, it is the temperature inside the waste body that affects $\mathrm{CH}_{4}$ generation rather than ambient temperature. Moreover, temperature affects the diffusional gas transport according to Fick's law, as the diffusion coefficient is temperature dependent. However, gas collection at landfills depends mainly on the advective gas transport caused by the applied suction pressure of the gas collection system (Xu et al., 2014) rather than diffusional gas transport. This explains the lack of correlation between ambient temperatures and LFG data.

\subsubsection{Wind speed}

In general, very low correlation coefficients were observed between wind speed and LFG $\mathrm{CH}_{4}$ concentration, LFG flow and $\mathrm{CH}_{4}$ flow (Table 2). A previous modelling study (Poulsen, 2005) has 
shown that wind turbulence can affect gas emissions from landfills, especially in winter, when the moisture content of the cover soil is higher and winds are stronger. Therefore, we studied the correlation in each separate period of 2016, as this year's readings included both summer and winter.

Table 3 shows the calculated correlation coefficient and p-values between wind speed and LFG data in 2016. Very weak correlations were observed between wind speed and LFG data during the periods in summer (15.08.2016-25.08.2016 and 05.09.2016-11.09.2016), while a strong and statistically significant correlation was observed in winter (05.12.2016-08.12.2016). Average wind speed during the winter period, namely 05.12.2016-08.12.2016 (3.5 m/s), was approximately twice the average wind speed during the summer periods 11.08.2015-06.09.2015 (2.1 m/s), 15.08.2016-25.08.2016 (1.3 m/s) and 05.09.2016-11.09.2016 (1.7 m/s).

The correlation seen during winter was positive with LFG $\mathrm{CH}_{4}$ concentrations and negative with LFG flow, meaning that higher wind speeds resulted in higher LFG $\mathrm{CH}_{4}$ concentrations and lower LFG flows. As an example, on 06.12.2016 00:00-07:00, a decrease in wind speed from 4.3 to $0.7 \mathrm{~m} / \mathrm{s}$ led to a decrease in $\mathrm{LFG} \mathrm{CH}_{4}$ concentration from 33.6 to $32.6 \%$, and an increase in LFG flow from 493 to $511 \mathrm{Nm}^{3} / \mathrm{h}$.

Table 3. Correlation coefficient between wind speed and barometric pressure and LFG data during the studied periods in 2016.

\begin{tabular}{lllllll}
\hline Period & Parameter & $\mathrm{n}$ & $\begin{array}{l}\text { Barometric } \\
\text { pressure (mbar) }\end{array}$ & $\begin{array}{l}\text { LFG } \\
\text { concentration } \\
(\%)\end{array}$ & $\begin{array}{l}\mathrm{CH}_{4} \\
\left(\mathrm{Nm}^{3} / \mathrm{h}\right)\end{array}$ & $\begin{array}{l}\mathrm{CH}_{4} \text { flow } \\
\left(\mathrm{Nm}^{3} / \mathrm{h}\right)\end{array}$ \\
\hline 15.08.2016-25.08.2016 & Wind speed (m/s) & 212 & $0.09(p \geq 0.10)$ & $-0.10(p \geq 0.10)$ & $0.09(p \geq 0.10)$ & $0.05(p \geq 0.10)$ \\
$05.09 .2016-11.09 .2016$ & Wind speed (m/s) & 144 & $-0.04(p \geq 0.10)$ & $-0.13(p \geq 0.10)$ & $0.15(0.05 \leq p<0.10)$ & $0.30(p<0.001)$ \\
$05.12 .2016-08.12 .2016$ & Wind speed (m/s) & 88 & $-0.91(p<0.001)$ & $0.75(p<0.001)$ & $-0.77(p<0.001)$ & $0.26(0.01 \leq p<$ \\
& & & & & $0.05)$ \\
\hline
\end{tabular}


Fig. 5 shows wind speed against $\mathrm{LFG} \mathrm{CH} 4$ concentration (5a), LFG flow (5b) and $\mathrm{CH}_{4}$ flow (5c) during 05.12.2016-08.12.2016. Graphs illustrating wind speed against LFG CH4 concentration, LFG flow and $\mathrm{CH}_{4}$ flow during the rest of the studied periods are provided in the SM (Figs. A7-A9). Generally, it is notable from the figures that winds were stronger in winter in comparison to summer. Visually, a strong correlation was observed between wind speed and $\mathrm{CH}_{4}$ concentrations and LFG flow during winter 2016 (Fig. 5), but not during summer 2015 (Fig. A7) or summer 2016 (Figs. A8 and A9). CH4 flow did not show a strong correlation with wind speed during winter 2016, most likely because of the fairly constant $\mathrm{CH}_{4}$ flow in 2016, due to the regulatory measure of the gas engine as previously discussed.

Wind speed correlated highly and inversely with barometric pressure in winter (Table 3, $\mathrm{r}=-0.91$, $p<0.001)$. However, with the analysis performed in this study, it was not possible to determine the cause and effect relationship between these two parameters. A very weak correlation was observed between wind speed and barometric pressure in summer 2016 (Table 3). This is in line with McBain et al. (2005) who found a weak correlation between wind speed and barometric pressure in June-August 2002.

Some previous studies have suggested wind-induced advection as the dominant $\mathrm{CH}_{4}$ emission mechanism in windy conditions at landfills (Poulsen, 2005; Xin et al., 2016) and wetlands (Kim et al., 1998). Wind blowing across irregular topography (such as a landfill) can cause a pressure difference, which is the driving force for advective gas transportation (Massman et al., 1997; Poulsen, 2005). This is suggested by Massman et al. (1997) as one of the mechanisms behind "pressure pumping" or advective gas transportation, which is caused by development of pressure fields on the surface induced by wind blowing. This could mean that wind speed - when strong enough - creates a pressure 
difference between landfill body and the landfill surface, which then affect gas extraction and emissions from landfills.
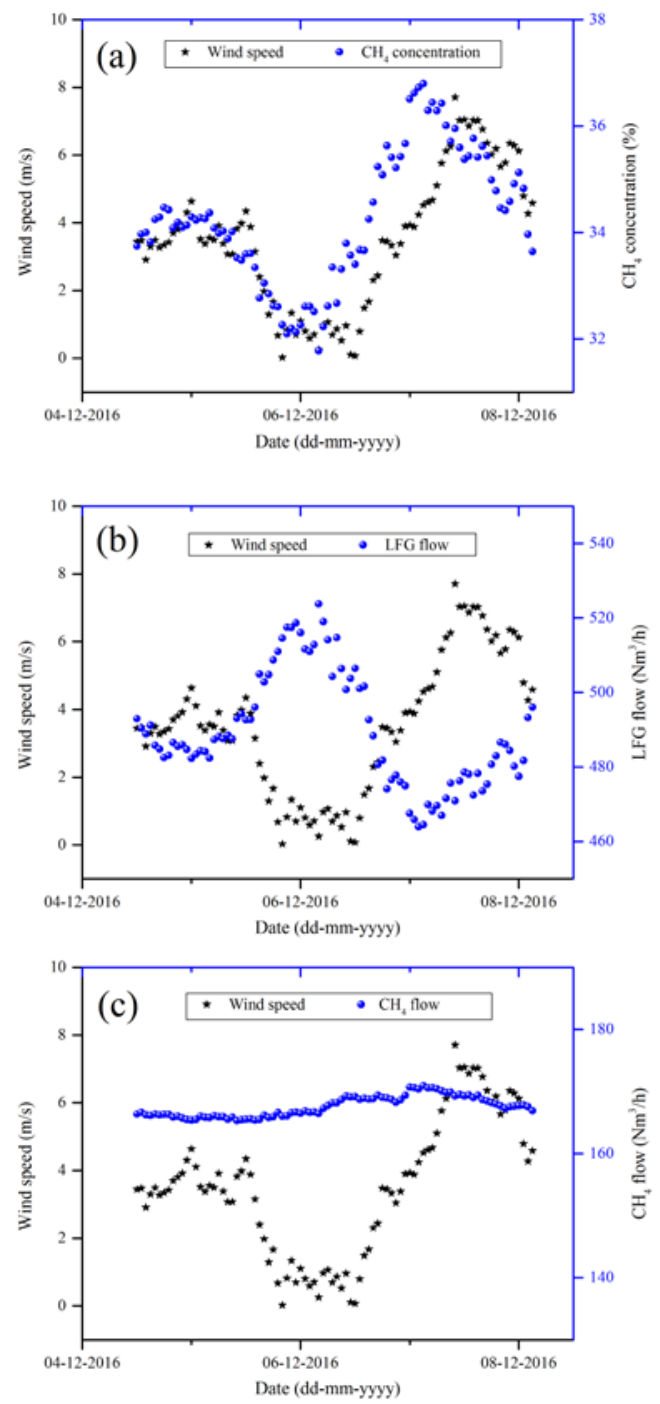

Fig. 5. Wind speed (m/s) against LFG $\mathrm{CH}_{4}$ concentration (\%), LFG flow $\left(\mathrm{Nm}^{3} / \mathrm{h}\right)$ and $\mathrm{CH}_{4}$ flow $\left(\mathrm{Nm}^{3} / \mathrm{h}\right)$ during 05.12.2016-08.12.2016.

Advective landfill gas transportation is more important than gas diffusion in a low permeability medium (Poulsen, 2005). Cover soils with higher moisture content have lower permeability. The moisture content of the cover soils is usually higher in winter, and winds are often stronger. Thus, 
stronger winds coinciding with high moisture content of the soil cover can potentially result in windinduced advection.

Apart from the soil moisture and wind speed, the type of vegetation can affect the importance of windinduced gas transport at landfills (Xin et al., 2016). For instance, in a study by Xin et al. (2016) a strong correlation between wind speed and $\mathrm{CH}_{4}$ emissions at night was observed at landfill areas covered with the plant species Setaria viridis, but not in the landfill areas covered with Neyraudia reynaudiana. Parts of Stige $\varnothing$ landfill is covered with vegetation. However, investigating the role of different vegetation at Stige $\varnothing$ landfill on the impact of wind speed on gas collection at this landfill was not the objective of this study and remains a topic to be studied in the future.

\subsubsection{Solar radiation}

A very weak correlation (absolute value of $\mathrm{r}$ between $0.03-0.21$ ) was observed between solar radiation and LFG data (Table 2). Graphs illustrating solar radiation against LFG $\mathrm{CH}_{4}$ concentration, LFG flow and $\mathrm{CH}_{4}$ flow during 11.08.2015-06.09.2015 can be found in the SM (Fig. A10). No visual correlation was observed between solar radiation and LFG data. Furthermore, studying the three periods in 2016 separately resulted in very weak correlation coefficients (absolute value of $r$ between 0-0.21) between solar radiation and LFG data. This showed that solar radiation does not appear to be an important factor affecting LFG collection rates and composition.

Xin et al. (2016) observed a high positive correlation between solar radiation and $\mathrm{CH}_{4}$ emissions from vegetation-covered areas of a Chinese landfill during daytime hours. Xin et al. (2016) suggested that increasing solar radiation results in internal pressurization of plants, which results in advective $\mathrm{CH}_{4}$ emissions from the plants. If the solar radiation affects the $\mathrm{CH}_{4}$ emissions, it could potentially affect the 
$\mathrm{CH}_{4}$ collection as well. However, in our study we did not see an influence of solar radiation on LFG collection data. This could be due to the fact that Odense Nord landfill and parts of Stige Ø landfill are not covered with vegetation, or it could be related to the type of vegetation at Stige Ø landfill.

Solar radiation affects temperature, which is a key factor in diffusive gas transport in landfills (Xin et al., 2016). However, as previously discussed, gas transport at landfills with an active gas collection system depends mainly on the applied suction pressure (advection gas transport) (Xu et al., 2014), and as a result, diffusive gas transport becomes less important. Apart from affecting diffusive gas transportation, solar radiation can affect cover soil temperature, which influences $\mathrm{CH}_{4}$ oxidation and emissions at landfills (Börjesson and Svensson, 1997; Christophersen et al., 2001; Scheutz et al., 2009). However, as previously discussed, the temperature inside landfills, which affects LFG generation, can be different than soil and ambient temperature explaining the lack of correlation between solar radiation and the recovered LFG data in this study.

Overall, wind speed in winter and barometric pressure were the meteorological parameters that showed high correlations - statistically and visually - with LFG $\mathrm{CH}_{4}$ concentrations, LFG flows and $\mathrm{CH}_{4}$ flows entering the gas engine. Nevertheless, barometric pressure and wind speed were studied separately in this study (univariate analysis), and their simultaneous impact on LFG recovery was not studied. An investigation into the simultaneous impact of these two parameters requires a multivariate data analysis, which remains a topic for future study. Moreover, it should be noted that in this study the impact of meteorological parameters was studied over periods of few days to approximately one month, while the impact of some parameters such as ambient temperature or solar radiation might be more important over a 24-hour time period. 


\subsection{Impact of changes in barometric pressure on $\mathrm{LFG} \mathrm{CH}_{4}$ concentration, $\mathrm{LFG}$ flow and $\mathrm{CH}_{4}$}

flow

The impact of changes in barometric pressure on $\mathrm{LFG} \mathrm{CH}_{4}$ concentration, $\mathrm{LFG}$ flow and $\mathrm{CH}_{4}$ flow was studied by dividing the measuring periods into sub-periods based on increasing and decreasing pressure, which resulted in 13 periods in 2015 and 13 periods in 2016. An example is shown in Fig. 2 in which black vertical lines delineate the division into sub-periods. The calculated magnitudes of changes in barometric pressure, $\mathrm{LFG} \mathrm{CH}_{4}$ concentration, $\mathrm{LFG}$ flow and $\mathrm{CH}_{4}$ flow can be found in Table A1 and Table A2 of the SM. The results of the statistical analysis performed on the calculated changes can be seen in Table 4.

Table 4. Correlation coefficient between changes in barometric pressure and changes in LFG data during the studied periods in 2015 and 2016.

\begin{tabular}{llllll}
\hline Year & Parameter & $n$ & $\begin{array}{l}\Delta \mathrm{LFG} \mathrm{CH}_{4} \text { concentration } \\
(\%)\end{array}$ & $\Delta \mathrm{LFG}$ flow $\left(\mathrm{Nm}^{3} / \mathrm{h}\right)$ & $\Delta \mathrm{CH}_{4}$ flow $\left(\mathrm{Nm}^{3} / \mathrm{h}\right)$ \\
\hline 2015 & $\Delta \mathrm{P}$ (mbar) & 13 & $-0.93(p<0.001)$ & $0.85(p<0.001)$ & $-0.80(p<0.001)$ \\
2016 & $\Delta \mathrm{P}$ (mbar) & 13 & $-0.81(0.001 \leq p<0.01)$ & $0.89(p<0.001)$ & $0.20(p \geq 0.10)$ \\
\hline
\end{tabular}

The results show that changes in barometric pressure correlated strongly with changes in $\mathrm{CH}_{4}$ concentration, $\mathrm{LFG}$ flow and $\mathrm{CH}_{4}$ flow, and the correlation was statistically significant $(p<0.01)$. The correlation was also observed in scatterplots (Figs. A11 and A12 of the SM). A negative correlation was observed between changes in barometric pressure and LFG $\mathrm{CH}_{4}$ concentration and $\mathrm{CH}_{4}$ flow, while a positive correlation was observed with LFG flow. This means that increasing barometric pressure results in decreasing $\mathrm{LFG} \mathrm{CH}_{4}$ concentration and $\mathrm{CH}_{4}$ flow, as well as increasing LFG flow.

The reason for these results could be that when barometric pressure increased, atmospheric air flowed into the landfill, which resulted in the higher collection of LFG by the gas recovery system, while the recovered gas was more diluted and thus had a lower $\mathrm{CH}_{4}$ concentration. The lower $\mathrm{CH}_{4}$ flow could be 
a result of $\mathrm{CH}_{4}$ oxidation and/or aerobic waste decomposition when air is pushed into the landfilled waste volume. Gebert and Groengroeft (2006) observed in a previous study that increasing barometric pressure resulted in higher $\mathrm{O}_{2}$ and lower $\mathrm{CH}_{4}$ content of LFG.

Table 5 shows calculated correlation coefficients and p-values between the gradient of changes in barometric pressure over time and the gradient of changes in LFG data over time. The calculated gradient of changes in barometric pressure, $\mathrm{CH}_{4}$ concentration, $\mathrm{LFG}$ flow and $\mathrm{CH}_{4}$ flow can be found in Table A3 and Table A4 of the SM. A high correlation was observed between the gradient of changes in barometric pressure and gradient of changes in $\mathrm{CH}_{4}$ concentration, $\mathrm{LFG}$ flow and $\mathrm{CH}_{4}$ flow (Table 5). Correlations were also observed in scatterplots (Figs. A13 and A14 of the SM). When comparing Table 4 and Table 5, it is evident that lower correlation coefficients were observed by studying the gradient of changes in barometric pressure $(\Delta \mathrm{P} / \Delta \mathrm{t})$ in comparison to the magnitude of changes in barometric pressure $(\Delta \mathrm{P})$. This means that by studying the magnitude of changes in barometric pressure for whole periods of rising or falling barometric pressure $(\Delta \mathrm{P})$, a higher impact on LFG data (especially on $\mathrm{LFG} \mathrm{CH}_{4}$ centration and LFG flow) can be expected in comparison to studying the gradient of changes in barometric pressure for one hour $(\Delta \mathrm{P} / \Delta \mathrm{t})$.

Table 5. Correlation coefficient between gradient of changes in barometric pressure over time and gradient of changes in LFG data over time, during the studied periods in 2015 and 2016.

\begin{tabular}{|c|c|c|c|c|c|}
\hline \multirow[t]{2}{*}{ Year } & \multirow[t]{2}{*}{ Parameter } & \multirow[t]{2}{*}{$n$} & $\Delta \mathrm{LFG}$ & flow $/ \Delta \mathrm{t}$ & flow $/ \Delta \mathrm{t}$ \\
\hline & & & concentration/ $\Delta \mathrm{t}(\% / \mathrm{h})$ & $\left(\mathrm{Nm}^{3} / \mathrm{h} / \mathrm{h}\right)$ & $\left(\mathrm{Nm}^{3} / \mathrm{h} / \mathrm{h}\right)$ \\
\hline 2015 & $\Delta \mathrm{P} / \Delta \mathrm{t}(\mathrm{mbar} / \mathrm{h})$ & 13 & $-0.87(p<0.001)$ & $0.58(0.01 \leq p<0.05)$ & $-0.87(p<0.001)$ \\
\hline 2016 & $\Delta \mathrm{P} / \Delta \mathrm{t}(\mathrm{mbar} / \mathrm{h})$ & 13 & $-0.62(0.01 \leq p<0.05)$ & $0.74(0.001 \leq p<0.01)$ & $0.21(p \geq 0.10)$ \\
\hline
\end{tabular}

The magnitude and gradient of changes in barometric pressure did not show a strong correlation with the magnitude and gradient of changes in $\mathrm{CH}_{4}$ flow in 2016 (Table 4 and 5), because of the fairly 
constant $\mathrm{CH}_{4}$ flow in 2016, due to the gas engine's regulatory measure, as already discussed in previous sections.

Changes in barometric pressure showed higher correlation coefficients with $\mathrm{CH}_{4}$ concentration, LFG flow and $\mathrm{CH}_{4}$ flow (Table 4 and 5) in comparison to the absolute value of barometric pressure (Table 2). However, it should be noted that the numbers of observations ( $n$ ) when studying barometric pressure were much higher than the numbers of observations when studying changes in barometric pressure. When $n$ increases, a lower absolute correlation coefficient can still mean a strong correlation (Reimann et al., 2008).

Table 6 shows the slope of the linear regression between the magnitude and gradient of changes in barometric pressure ( $\Delta \mathrm{P}$ and $\Delta \mathrm{P} / \Delta \mathrm{t}$, respectively) as the independent variable, while the magnitude and gradient of changes in LFG data (LFG $\mathrm{CH}_{4}$ concentration, LFG flow and $\mathrm{CH}_{4}$ flow) is the dependent variable. These slopes can be used for estimating changes in recovered LFG flow and composition according to changes in barometric pressure. For instance, a 5-mbar decrease in barometric pressure is expected to increase $\mathrm{LFG} \mathrm{CH}_{4}$ concentration by about $1 \%$ and decrease $\mathrm{LFG}$ flow by $4.4 \mathrm{Nm}^{3} / \mathrm{h}$ when the gas engine has not reached maximum capacity (2015). Similarly, when the gas engine is running on

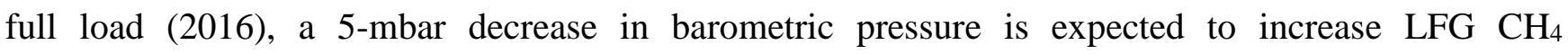
concentration by about $1.3 \%$ and decrease LFG flow by $17.3 \mathrm{Nm}^{3} / \mathrm{h}$. However, the slopes calculated in this study may not be applicable to other landfills, as gas collection at landfills depends on many factors, including the design and management of the gas collection system and the presence and type of top cover. 
Table 6. Slope of the linear regression analysis performed on changes in LFG data as a function of changes in barometric pressure.

\begin{tabular}{|c|c|c|c|c|c|c|}
\hline Year & $\begin{array}{l}\Delta \mathrm{CH}_{4} \\
\text { concentration } \\
\text { vs. } \Delta \mathrm{P} \\
(\% / \text { mbar })\end{array}$ & $\begin{array}{l}\Delta \mathrm{LFG} \\
\text { flow } \quad \text { vs. } \\
\Delta \mathrm{P} \\
\left(\mathrm{Nm}{ }^{3} / \mathrm{h} /\right. \\
\text { mbar) }\end{array}$ & $\begin{array}{l}\Delta \mathrm{CH}_{4} \text { flow } \\
\text { vs. } \Delta \mathrm{P} \\
\left(\mathrm{Nm}^{3} / \mathrm{h} /\right. \\
\text { mbar })\end{array}$ & $\begin{array}{l}\Delta \mathrm{CH}_{4} \\
\text { concentration } / \Delta \mathrm{t} \\
\text { vs. } \Delta \mathrm{P} / \Delta \mathrm{t} \\
(\% / \mathrm{mbar})\end{array}$ & $\begin{array}{l}\Delta \mathrm{LFG} \text { flow } / \Delta \mathrm{t} \\
\text { vs. } \Delta \mathrm{P} / \Delta \mathrm{t} \\
\left(\mathrm{Nm}^{3} / \mathrm{h} / \mathrm{mbar}\right)\end{array}$ & $\begin{array}{l}\Delta \mathrm{CH}_{4} \text { flow } / \Delta \mathrm{t} \\
\text { vs. } \Delta \mathrm{P} / \Delta \mathrm{t} \\
\left(\mathrm{Nm}^{3} / \mathrm{h} / \mathrm{mbar}\right)\end{array}$ \\
\hline 2015 & -0.19 & 0.87 & -0.57 & -0.28 & 0.87 & -0.99 \\
\hline 2016 & -0.26 & 3.46 & $-^{\mathrm{a}}$ & -0.28 & 4.02 & $-^{\mathrm{a}}$ \\
\hline
\end{tabular}

a: $\mathrm{CH}_{4}$ flow was constant, as the gas engine had reached its maximum capacity and thus determining the slope was not possible.

A number of previous studies (Fredenslund et al., 2010; Gebert and Groengroeft, 2006; Poulsen et al., 2003; Xu et al., 2014; Young, 1992) have concluded that it is changes in barometric pressure that affect $\mathrm{CH}_{4}$ emissions from landfills, rather than absolute values. For instance, Fredenslund et al. (2010) observed an increase in measured emissions from 0.2 to $4.7 \mathrm{~kg} \mathrm{CH}_{4} / \mathrm{d}$ when barometric pressure decreased by 12 mbar. Another example is the study by Xu et al. (2014), who observed lower average $\mathrm{CH}_{4}$ emission fluxes during periods of increasing barometric pressure $\left(12.3 \mu \mathrm{mol} / \mathrm{m}^{2} / \mathrm{s}\right)$ in comparison to periods of decreasing barometric pressure $\left(22.9 \mu \mathrm{mol} / \mathrm{m}^{2} / \mathrm{s}\right)$.

However, in our study, $\mathrm{LFG} \mathrm{CH}_{4}$ concentration, LFG flow and $\mathrm{CH}_{4}$ flow correlated highly with both absolute barometric pressure and changes in barometric pressure, and higher correlations were observed when studying changes in barometric pressure in comparison to the absolute value of barometric pressure. This is in line with Christophersen et al. (2001), who found that $\mathrm{CH}_{4}$ emissions correlated with both barometric pressure and the pressure gradient, while a higher correlation was observed when studying the barometric pressure gradient.

\section{Conclusions and perspectives}

The impact of barometric pressure, ambient temperature, wind speed and solar radiation on recovered landfill gas (LFG) flow, $\mathrm{CH}_{4}$ content of the $\mathrm{LFG}$ and recovered $\mathrm{CH}_{4}$ flow was studied by performing 
statistical correlation tests and a visual check on correlations in scatterplots. Furthermore, the effect of changes in barometric pressure on the collected LFG data was studied. Recovered LFG flow, its $\mathrm{CH}_{4}$ content and recovered $\mathrm{CH}_{4}$ flow correlated highly with both the absolute value of barometric pressure and changes in barometric pressure, and these correlations were statistically significant. The correlation was negative for recovered $\mathrm{CH}_{4}$ concentration and flow, while a positive correlation was observed for LFG flow. A higher correlation coefficient was observed when studying changes in barometric pressure in comparison to studying absolute value of barometric pressure. A high and statistically significant correlation was observed between wind speed and the collected LFG data in winter, but not in summer. Recovered LFG flow, its $\mathrm{CH}_{4}$ content and recovered $\mathrm{CH}_{4}$ flow were correlated only weakly with ambient temperature and solar radiation. This showed that ambient temperature and solar radiation were not major meteorological parameters affecting LFG collection.

These findings are important for the purpose of optimised gas collection from landfills. It is recommended that landfill operators monitor barometric pressure and wind speed and regulate the gas recovery system accordingly. The better regulation of the gas recovery system could result in lower $\mathrm{CH}_{4}$ emissions from landfills and thus lower their contribution to global warming. Moreover, it is recommended to take into account barometric pressure and wind speed when performing whole-site emission measurements.

\section{Acknowledgments}

The authors would like to thank Rasmus Olsen (civil engineer) and Ulrik Lønkjær (landfill gas engineer) from Odense Nord Miljøcenter for their help during data collection. We would also like to 
thank researcher Maklawe Essonanawe Edjabou (DTU Environment) for his contribution to the statistical analysis.

\section{References}

Bogner, J., Pipatti, R., Hashimoto, S., Diaz, C., Mareckova, K., Diaz, L., Kjeldsen, P., Monni, S., Faaij, A., Sutamihardja, R.T.M., Gregory, R., 2008. Mitigation of global greenhouse gas emissions from waste: conclusions and strategies from the Intergovernmental Panel on Climate Change (IPCC) Fourth Assessment Report. Working Group III (Mitigation). Waste Manage. Res. 26, 11-32. DOI: $10.1177 / 0734242 X 07088433$

Börjesson, G., Svensson, B.H., 1997. Seasonal and diurnal methane emissions from a landfill and their regulation by methane oxidation. Waste Manag. Res. 15, 33-54.

Chanton, J., Liptay, K., 2000. Seasonal variation in methane oxidation in a landfill cover soil as determined by an in situ stable isotope technique. Global Biogeochem. Cycles 14, 51-60. doi:10.1029/1999GB900087

Chen, Y., Cheng, J.J., Creamer, K.S., 2008. Inhibition of anaerobic digestion process: A review. Bioresour. Technol. 99, 4044-4064. doi:10.1016/j.biortech.2007.01.057

Christophersen, M., Kjeldsen, P., Holst, H., Chanton, J., 2001. Lateral gas transport in soil adjacent to an old landfill: factors governing emissions and methane oxidation. Waste Manag. Res. 19, 595612. doi:10.1177/0734242X0101900616

Czepiel, P.M., Shorter, J.H., Mosher, B., Allwine, E., McManus, J.B., Harriss, R.C., Kolb, C.E., Lamb, B.K., 2003. The influence of atmospheric pressure on landfill methane emissions. Waste Manag. 
23, 593-598. doi:10.1016/S0956-053X(03)00103-X

Filzmoser, P. 2015. StatDA: Statistical Analysis for Environmental Data. R package version 1.6.9. https://CRAN.R-project.org/package=StatDA

Fredenslund, A.M., Scheutz, C., Kjeldsen, P., 2010. Tracer method to measure landfill gas emissions from leachate collection systems. Waste Manag. 30, 2146-2152. doi:10.1016/j.wasman.2010.03.013

Gebert, J., Groengroeft, A., 2006. Passive landfill gas emission - Influence of atmospheric pressure and implications for the operation of methane-oxidising biofilters. Waste Manag. 26, 245-251. doi:10.1016/j.wasman.2005.01.022

Hanson, J.L., Yeşiller, N., Oettle, N.K., 2010. Spatial and Temporal Temperature Distributions in Municipal Solid Waste Landfills. J. Environ. Eng. 136, 804-814. doi:10.1061/?ASCE?EE.1943$7870.0000202 \mathrm{CE}$

IPCC, 2013. Stocker, T.F., Qin, D.H., Plattner, G.K., Tignor, M.M.B., Allen, S.K., Boschung, J., Nauels, A., Xia, Y., Bex, V., Midgley, P.M. Climate Change 2013: The Physical Science Basis. Contribution of Working Group I to the Fifth Assessment Report of the Intergovernmental Panel on Climate Change. Cambridge University Press, Cambridge, United Kingdom and New York, NY, USA.

Kim, J., Verma, S.B., Billesbach, D.P., Clement, R.J., 1998. Diel variation in methane emission from a midlatitude prairie wetland: Significance of convective throughflow in Phragmites australis. J. Geophys. Res. 103, 28029-28039. 
Kitzing, L., Katz, J., Schröder, S. T., Morthorst, P. E., \& Møller Andersen, F., 2016. The residential electricity sector in Denmark: A description of current conditions. Department of Management Engineering, Technical University of Denmark.

Massman, W.J., Sommerfeld, R.A., Mosier, A.R., Zeller, K.F., Hehn, T.J., Rochelle, S.G., 1997. A model investigation of turbulence-driven pressure-pumping effects on the rate of diffusion of $\mathrm{CO}_{2}$ , $\mathrm{N}_{2} \mathrm{O}$, and $\mathrm{CH}_{4}$ through layered snowpacks. J. Geophys. Res. 102, 18851-18863.

McBain, M.C., Warland, J.S., McBride, R.A., Wagner-Riddle, C., 2005. Micrometeorological measurements of $\mathrm{N}_{2} \mathrm{O}$ and $\mathrm{CH}_{4}$ emissions from a municipal solid waste landfill. Waste Manag. Res. 23, 409-419. doi:10.1177/0734242X05057253

Nastev, M., Therrien, R., Lefebvre, R., Gélinas, P., 2001. Gas production and migration in landfills and geological materials. J. Contam. Hydrol. 52, 187-211. doi:10.1016/S0169-7722(01)00158-9

Nwachukwu, a. N., Anonye, D., 2013. The effect of atmospheric pressure on $\mathrm{CH}_{4}$ and $\mathrm{CO}_{2}$ emission from a closed landfill site in Manchester, UK. Environ. Monit. Assess. 185, 5729-5735. doi:10.1007/s10661-012-2979-0

Olsen, R., Willumsen, H.C., 2013. Characterization of Gas , Heat and Humidity Profiles in Landfilled Shredder Residue At Odense Nord Landfill , Denmark. Sardinia 2013, Proc. Fourteenth Int. Waste Manag. Landfill Symp. 30 Sept. 4 October, Sardinia, Italy.

Poulsen, T.G., 2005. Impact of wind turbulence on landfill gas emissions. Proc. Sardinia 2005, Tenth Int. Waste Manag. Landfill Symp. S. Margherita di Pula, Cagliari, Italy; 3 - 7 Oct. 2005.

Poulsen, T.G., Christophersen, M., Moldrup, P., Kjeldsen, P., 2003. Relating landfill gas emissions to 
atmospheric pressure using numerical modelling and state-space analysis. Waste Manag. Res. 21, $356-366$.

R Core Team. 2017. R: A language and environment for statistical computing. R Foundation for Statistical Computing, Vienna, Austria. URL https://www.R-project.org/.

Reimann, C., Filzmoser, P., Garrett, R.G., Dutter, R., 2008. Statistical Data Analysis Explained: Applied Environmental Statistics with R. John Wiley \& Sons, Ltd. Chichester, England.

Scheutz, C., Kjeldsen, P., Bogner, J.E., De Visscher, A., Gebert, J., Hilger, H. a, Huber-Humer, M., Spokas, K., 2009. Microbial methane oxidation processes and technologies for mitigation of landfill gas emissions. Waste Manag. Res. 27, 409-455. doi:10.1177/0734242X09339325

Uyanik, I., Ozkaya, B., Demir, S., Cakmakci, M., 2012. Meteorological parameters as an important factor on the energy recovery of landfill gas in landfills. J. Renew. Sustain. Energy 4, 1-9. doi:10.1063/1.4769202

Waldheim, L., Nilsson, T., 2001. Heating value of gases from biomass gasification. IEA Bioenergy Agreement, Task 20 - Therm. Gasif. Biomass.

Xin, D., Hao, Y., Shimaoka, T., Nakayama, H., Chai, X., 2016. Site specific diel methane emission mechanisms in landfills: A field validated process based on vegetation and climate factors. Environ. Pollut. 218, 673-680. doi:10.1016/j.envpol.2016.07.060

Xu, L., Lin, X., Amen, J., Welding, K., McDermitt, D., 2014. Impact of changes in barometric pressure on landfill methane emission. Global Biogeochem. Cycles 28, 679-695. doi:10.1002/2013GB004571 
Young, A., 1990. Volumetric changes in landfill gas flux in response to variations in atmospheric pressure. Waste Manag. Res. 8, 379-385. doi:10.1016/0734-242X(90)90077-Z

Young, A., 1992. The effects of fluctuations in atmospheric pressure on landfill gas migration and composition. Water, Air, Soil Pollut. 64, 601-616. doi:10.1007/BF00483369 